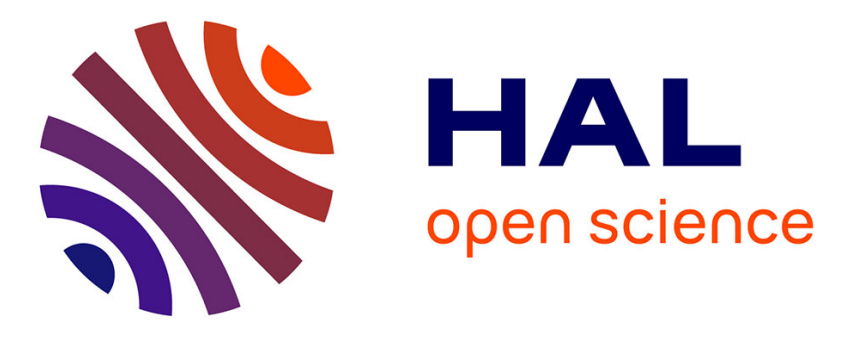

\title{
Properties of soluble acid phosphatases in an ectomycorrhizal fungus and in host plants subjected or not to Pi starvation
}

Claude Berjaud, Patrick Doumas, Michel Coupé, Jean d'Auzac

\section{- To cite this version:}

Claude Berjaud, Patrick Doumas, Michel Coupé, Jean d'Auzac. Properties of soluble acid phosphatases in an ectomycorrhizal fungus and in host plants subjected or not to Pi starvation. Agronomie, 1987, 7 (2), pp.95-99. hal-00884973

\section{HAL Id: hal-00884973 https://hal.science/hal-00884973}

Submitted on 1 Jan 1987

HAL is a multi-disciplinary open access archive for the deposit and dissemination of scientific research documents, whether they are published or not. The documents may come from teaching and research institutions in France or abroad, or from public or private research centers.
L'archive ouverte pluridisciplinaire HAL, est destinée au dépôt et à la diffusion de documents scientifiques de niveau recherche, publiés ou non, émanant des établissements d'enseignement et de recherche français ou étrangers, des laboratoires publics ou privés. 


\section{Properties of soluble acid phosphatases in an ectomycorrhizal fungus and in host plants sub- jected or not to Pi starvation}

Claude BERJAUD, Patrick DOUMAS, Michel COUPÉ \& Jean d'AUZAC

Laboratoire de Physiologie végétale appliquée. Université des Sciences et Techniques du Languedoc, Place Eugène-Bataillon, F-34060 Montpellier Cedex

The phosphatases of an ectomycorrhizal fungus Pisolithus tinctorius (Pers.) Coker \& Couch. and of two pines Pinus pinaster Ait. and Pinus halepensis Mill. were studied in culture media with and without orthophosphate. Isophosphatases of the soluble fraction of each organism were separated by chromatography on DEAESepharose. Lack of phosphate induced two effects : either the increase of one or two particular isoenzymes, or the derepression of new phosphatases in the case of $P$. pinaster. The phosphatase activities of $P$. tinctorius were enhanced by phosphate starvation and these enzymes displayed a lower $\mathrm{Km}$ than those found in the pines. The phosphatases of the fungus were more inhibited by orthophosphate than the phosphatases of $P$. halepensis. The soluble acid phosphatases extracted from organisms previously Pi-starved exhibited a greater ability to hydrolyse the natural phosphorylated compounds present in soils (i.e. pyrophosphate, tripolyphosphate for $P$. tinctorius, pyrophosphate, tripolyphosphate, phytate for the pines).

Additional key words : Pisolithus tinctorius, Pinus halepensis, Pinus pinaster.

RÉSUMÉ

Propriétés de différentes phosphatases chez un champignon ectomycorhizogène et des plantes hôtes carencées ou non en Pi.

Les phosphatases d'un champignon ectomycorhizogène, $P$. tinctorius (Pers.) Coker \& Couch., et deux variétés de pins, $P$. pinaster Ait. et $P$. halepensis Mill., ont été étudiées lorsque le milieu de culture est carencé ou non en phosphate. Les différentes isophosphatases de la fraction soluble de chaque organisme ont été séparées par chromatographie sur DEAE-Sepharose. L'absence de phosphate induit deux effets : soit l'augmentation de l'activité d'une ou deux isoenzymes particulières, soit la dérepression de nouvelles phosphatases dans le cas de $P$. pinaster. Les phosphatases de $P$. tinctorius qui augmentent avec la carence en phosphate possèdent un $\mathrm{Km}$ inférieur à ceux trouvés chez les pins, qu'ils soient ou non mycorhizés. Les phosphatases du champignon sont davantage inhibées par le phosphate que celles de $P$. halepensis. Chez le champignon et les pins les phosphatases de la fraction soluble possèdent, en milieu carencé, une plus grande capacité d'hydrolyser les composés phosphorylés normalement présents dans les sols tels le pyrophosphate, le tripolyphosphate et le phytate.

Mots clés additionnels : Pisolithus tinctorius, Pinus halepensis, Pinus pinaster.

\section{INTRODUCTION}

Many authors have shown that phosphate deficiency causes an increase in phosphatase (Pase) activities in bacteria (TORRIANI, 1960), yeast (VAN RIJN et al., 1972), fungi (KOMANO, 1975 ; CALLÉJA et al., 1980) and higher plants (BOUTIN et al., 1981 ; DOUMAS et al., 1983 ; STROTHER, 1984). Phosphatase activities also increase during development of mycorrhizal infection (MOUSAIN \& SALSAC, 1982 ; GIANINAZZI-
PEARSON, 1982 ; DOUMAS, 1984). The ability of the fungal symbiont to produce acid phosphatases (EC 3.1.3.2) has been demonstrated in several studies (Ho \& ZAK, 1979 ; CALLÉJA \& d'AUZAC, 1983). These enzymes appear to play an important role in mycorrhizal utilization of soil phosphorus (BOWEN, 1973). Furthermore, changes in the biochemical properties of certain phosphatases, particularly in the fungal partner, during phosphate deficiency (NINOMIY.A et al., 1977) could help to explain the mechanisms involved in the improvement of phosphate nutrition. 


\section{MATERIAL AND METHODS}

\section{A. Organisms and cultivation}

Pinus halepensis Mill. and Pinus pinaster Ait, were cultivated under the conditions described by DouMAS (1984). Pisolithus tinctorius (Pers.) Coker \& Couch., strain F9, was cultivated in a liquid medium (CALLÉJA et al., 1980). The culture medium either contained no phosphate $(-\mathrm{P})$ or $2 \mathrm{mM}$ potassium phosphate $(+\mathrm{P})$. After 27 days of culture the thalli were collected, washed with $1 \%$ glucose and freeze-dried.

\section{B. Preparation of soluble fraction}

Fungus extraction was carried out in $50 \mathrm{mM}$ acetate buffer (pH 5.0); $5 \mathrm{mM}$ mercaptoethanol (MSH) ; $10 \mathrm{mM}$ ethylenediaminetetracetic acid (EDTA) and $5 \mathrm{mM}$ diethylethiocarbamate (DIECA) ; $1 \%$ Triton $\mathrm{X} 100$. During the grinding, polyvinylpyrrolidone (polyclar AT) was added as $0.1 \mathrm{mg}$ per gram of dry matter of the fungus. The soluble fraction was obtained by the method described by CALLÉJA et al. (1980). The soluble phosphatases of pines were obtained using the method described by Doumas (1984).

\section{Purification of soluble phosphatases}

The soluble phosphatases of $P$. tinctorius and of the two pines were obtained by filtration on an Ultrogel AcA202 column (IBF) and then separated by ionexchange chromatography on DEAE-Sepharose CL6B column (IBF). The proteins were eluted with a linear gradient $(0-0.4 \mathrm{M})$ of $\mathrm{NaCl}$. The buffer used for these two steps was a $25 \mathrm{mM}$ acetate buffer (pH 5.0); $5 \mathrm{mM} \mathrm{MSH}$ in the case of the fungus and a $25 \mathrm{mM}$ triethanolamine- $\mathrm{HCl}$ buffer $(\mathrm{pH} 7.5) ; 5 \mathrm{mM} \mathrm{MSH}$ in the case of the pines.

\section{Phosphatase assay}

Acid phosphatase activity was measured in the standard way with p-nitrophenylphosphate (pNPP) by the method described by COUPE \& d'AUZAC (1979). The inorganic phosphate released was determined by the TAUSSKY \& SHORR (1953) method. Activities are expressed as micromoles of $\mathrm{Pi}$ released per minute $\left(\mu \mathrm{mol} \mathrm{ml}^{-1} \mathrm{~min}^{-1}\right)$.

\section{RESULTS}

\section{A. DEAE-Sepharose chromatography of fungus and pine soluble acid phosphatases}

According to the spectra obtained from chromatography on DEAE-Sepharose of the phosphatases of $P$. halepensis and $P$. tinctorius, phosphate deficiency induced a similar effect in both organisms, i.e. a preferential increase in the activity of one of the phosphatases : Pase $\mathrm{T}^{-}$in the Pisolithus and Pase $\mathrm{H}^{-}$in the pine (Doumas et al., 1983) (fig. 1 and fig. 2). In

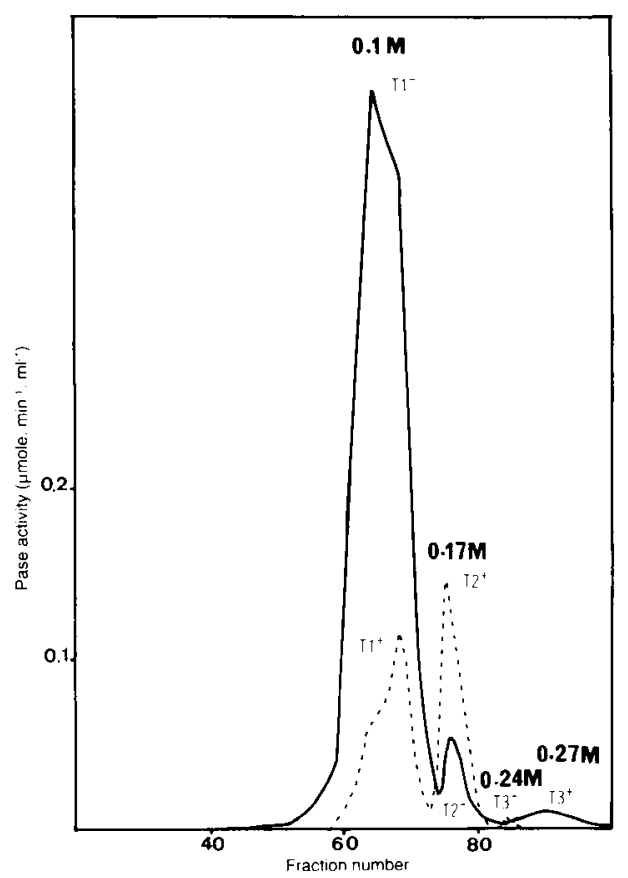

Figure 1

DEAE-Sepharose chromatography of soluble acid phosphatases from Pisolithus tinctorius.

$\mathrm{TI}^{+}, \mathrm{T2}^{+}, \mathrm{T3}^{+}$: phosphatases from Pisolithus cultivated on a Pisupplied medium.

$\mathrm{TI}^{-}, \mathrm{T2}^{-}, \mathrm{T3^{- }}$ : phosphatases of Pisolithus cultivated on a Pideprived medium.

Figures above the peaks indicate the $\mathrm{NaCl}$ molarities corresponding to their elution.

Chromatographie sur DEAE-Sepharose des phosphatases acides solubles de Pisolithus tinctorius.

$\mathrm{Tl}^{+}, \mathrm{T2}^{+}, \mathrm{T3}^{+}$: phosphatases de Pisolithus cultivé sur un milieu non carencé en $P i$.

$\mathrm{TI}^{-}, \mathrm{T2}^{-}, \mathrm{T3}^{-}$: phosphatases de Pisolithus cultivé sur un milieu carencé en phosphate.

Les chiffres au-dessus des pics indiquent les molarités de $\mathrm{NaCl}$ correspondant à leur élution.

$P$. pinaster phosphate deficiency mainly increased the activity of Pase $\mathrm{P}_{1}{ }^{-}$but two other isoenzymes were derepressed by the deficiency (Pase $\mathrm{P} 0$ and $\mathrm{Pase} \mathrm{P}^{-}{ }^{-}$) (fig. 3).

\section{B. Comparison of fungus and pine soluble acid phos- phatases}

The Michaelis-Menten constants $(\mathrm{Km})$ are shown in Tables $1 \mathrm{a}, 1 \mathrm{~b}$ and $1 \mathrm{c}$. The $\mathrm{Km}$ values varied between 0.08 and $0.6 \mathrm{mM}$. Lack of phosphate did not seem to modify the affinity of the enzymes of $P$. tinctorius for pNPP. In the case of the pines, the phosphatases present during phosphate starvation showed little more affinity for pNPP than their analogues occuring in the non-starved pines. Examination of the phosphatases most influenced by phosphate deficiency (Pase $\mathrm{T1}^{-}$of Pisolithus, $\mathrm{H}^{-}$of $P$. halepensis, $\mathrm{P} 1^{-}$of $P$. pinaster) showed that Pase $\mathrm{T}^{-}$of the fungus had a lower $\mathrm{Km}$ value than Pase $\mathrm{H}^{-}$and $\mathrm{P}^{-}$. Inhibition constants (Ki) values showed that the phosphatases of Pisolithus were more sensitive to inorganic phosphate concentrations than phosphatases of $P$. halepensis. 


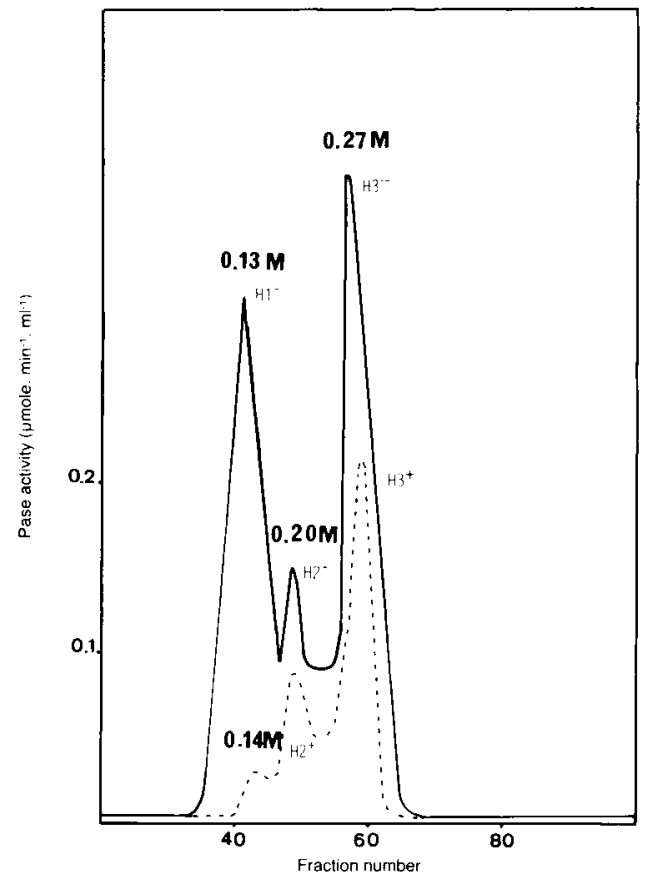

Figure 2

DEAE-Sepharose chromatography of soluble acid phosphatases from Pinus halepensis.

$\mathrm{HI}^{-}, \mathrm{H}^{-}, \mathrm{H}^{-}$: phosphatases from $\mathrm{P}$. tinctorius cultivated on a Pi-deprived medium.

$\mathrm{HI}^{+}, \mathrm{H}^{+}, \mathrm{H3}^{+}$: phosphatases from $\mathrm{P}$. tinctorius cultivated on a Pi-supplied medium.

Chromatographie sur DEAE-Sepharose des phosphatases acides solubles de Pinus halepensis.

$\mathrm{HI}^{-}, \mathrm{H2}^{-}, \mathrm{H3}^{-}$: phosphatases issues de $\mathrm{P}$. tinctorius cultivé en milieu carencé en $P i$.

$\mathrm{HI}^{+}, \mathrm{H}^{+}, \mathrm{H}^{+}$: phosphatases issues de $\mathrm{P}$. tinctorius cultivé en milieu non carencé en $P i$

Table 1

$\mathrm{Km}$ for $\mathrm{pNPP}(\mathrm{mM})$ and $\mathrm{Ki}$ for $\mathrm{KH}_{2} \mathrm{PO}_{4}(\mathrm{mM})$ of acid phosphatases of Pisolithus tinctorius (table la), Pinus halepensis (table $1 b$ ) and Pinus pinaster (table Ic) cultivated on a phosphorus-supplied $(+P)$ or a phosphorus-deprived medium ( $-P$ ).

$\mathrm{Km}$ pour le $\mathrm{pNPP}(\mathrm{mM})$ et $\mathrm{Ki}$ pour $\mathrm{KH}_{2} \mathrm{PO}_{4}(\mathrm{mM})$ des phosphatases acides de Pisolithus tinctorius (table la), de Pinus halepensis (table Ib) et de Pinus pinaster (table Ic) cultivés sur un milieu avec phosphate $(+P)$ ou sans phosphate $(-P)$.

* Pases mainly enhanced by phosphate starvation.

* Pases principalement exaltées par la carence en phosphate.

Table 1a

$+\mathrm{P}$

$$
-\mathrm{P}
$$

\begin{tabular}{lllll}
\hline \hline & $\mathrm{Ti}^{+*}$ & $\mathrm{~T}^{+}$ & $\mathrm{Ti}^{-}$ & $\mathrm{T}^{-}$ \\
\hline $\mathrm{Km}$ & 0,08 & 0,62 & 0,18 & 0,56 \\
$\sigma$ & 0,02 & 0,17 & 0,12 & 0,43 \\
\hline $\mathrm{Ki}$ & 3,5 & 3,6 & 2,5 & 0,45 \\
$\sigma$ & 0,68 & 0,6 & 0,5 & 0,04 \\
\hline \hline
\end{tabular}

Table $1 b$

\begin{tabular}{ccccccc}
\multicolumn{4}{c}{$+\mathrm{P}$} & \multicolumn{2}{c}{$-\mathrm{P}$} \\
\hline \hline & $\mathrm{H}^{+}$ & $\mathrm{H3}^{+}$ & $\mathrm{H}^{-*}$ & $\mathrm{H}^{-}$ & $\mathrm{H}^{-}$ \\
\hline $\mathrm{Km}$ & 0,5 & 0,25 & 1,5 & 1 & 0,5 \\
\hline $\mathrm{Ki}$ & - & 10,4 & 11 & 9,5 & 9,5 \\
\hline \hline
\end{tabular}

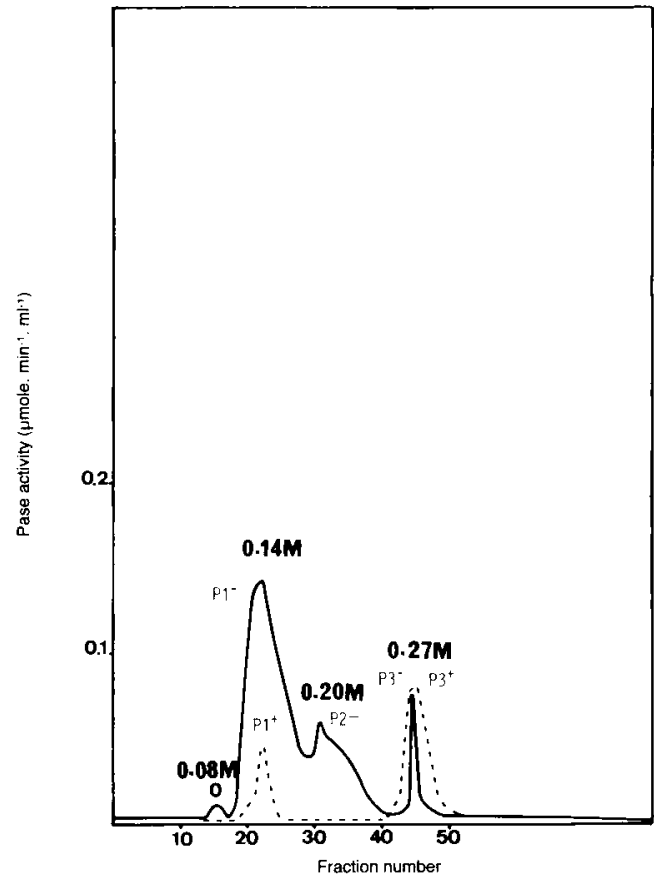

Figure 3

DEAE-Sepharose chromatography of soluble acid phosphatases from Pinus pinaster.

$\mathrm{Pl}^{-}, \mathrm{P2}^{-}, \mathrm{P3}^{-}$: phosphatases from $\mathrm{P}$. pinaster cultivated on a $\mathrm{Pi-}$ deprived medium.

$\mathrm{Pl}^{+}, \mathrm{P}^{+}$: phosphatases from $\mathrm{P}$. pinaster cultivated on a Pisupplied medium.

Chromatographie sur DEAE-Sepharose des phosphatases acides solubles de Pinus pinaster.

$P 1^{-}, P 2^{-}, P 3^{-}$: phosphatases issues de $\mathrm{P}$. pinaster cultivé en milieu carencé en Pi.

$\mathrm{Pl}^{+}, \mathrm{P3}^{+}$: phosphatases issues de $\mathrm{P}$. pinaster cultivé en milieu non carencé en $P i$.

\begin{tabular}{llll} 
& $\begin{array}{l}\text { Table } 1 \mathrm{c} \\
+\mathbf{P}\end{array}$ & \multicolumn{2}{c}{$-\mathrm{P}$} \\
\hline \hline $\mathrm{Km}$ & $\mathrm{P}^{+}$ & $\mathrm{P}^{-*}$ & $\mathrm{P}^{-}$ \\
\hline \hline
\end{tabular}

\section{Specificity of the phosphatases}

All the phosphatases studied in this paper are non specific as is generally the case for acid phosphatases. However these enzymes do not hydrolyse the different substrates at the same rate. The data for the pines and the fungus all indicated that the phosphate deficiency modified the hydrolysis efficiency of some substrates and especially those found naturally in the soil (trimetaphosphate, pyrophosphate, tripolyphosphate and phytate). This phenomenon was more marked for the phosphatases which were mainly increased by the phosphate deficiency $\left(\mathrm{H}^{-}\right.$for $P$. halepensis, $\mathrm{P}^{-}$for $P$. pinaster and $\mathrm{T}^{-}$for $P$. tinctorius) (fig. 4). We note that the hydrolysis of pNPP was less than that of the other substrates in the case of the fungal symbiont. 
a)
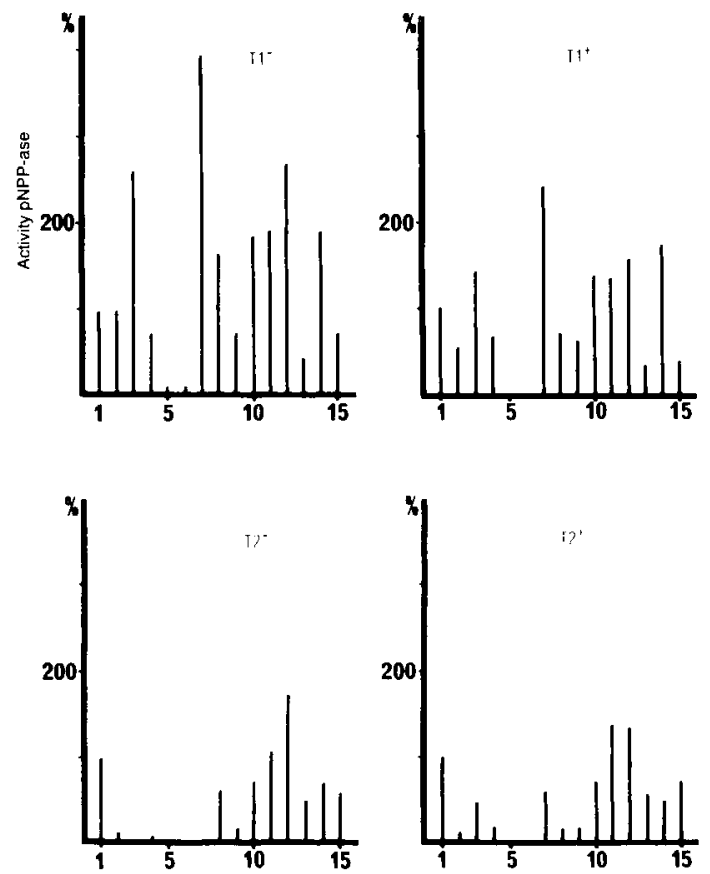

b)
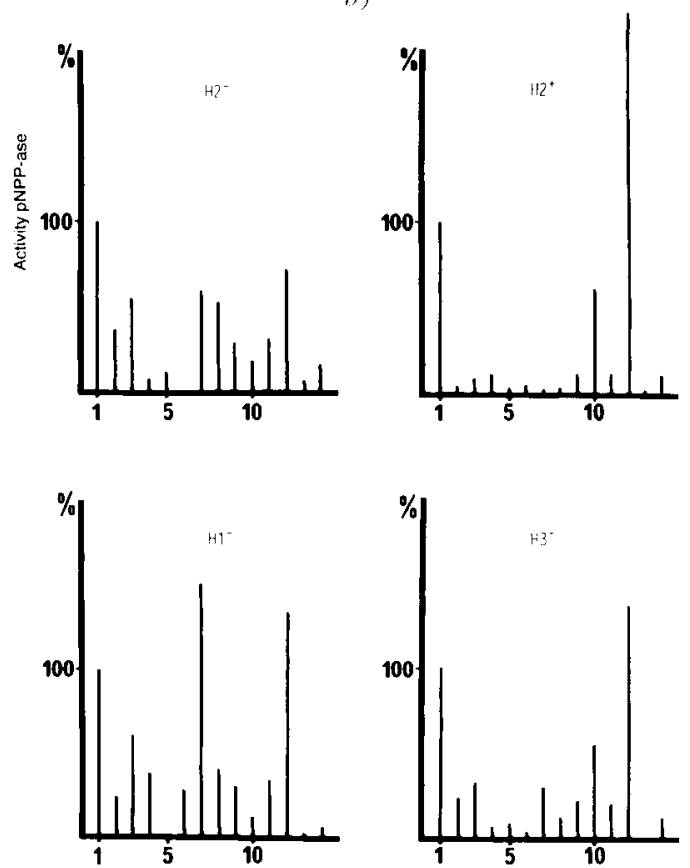

\section{DISCUSSION AND CONCLUSIONS}

These data show that during phosphate deficiency the fungus seems to be able to hydrolyse the phosphorylated substrates naturally occurring in the soil with a better efficiency than the pines. We can notice however that the phosphatases of $P$. tinctorius cannot hydrolyse the phytate, which is a widespread phosphorus substrate in the soils. Conversely the phosphatases of $P$. pinaster and even more those of $P$. halepensis
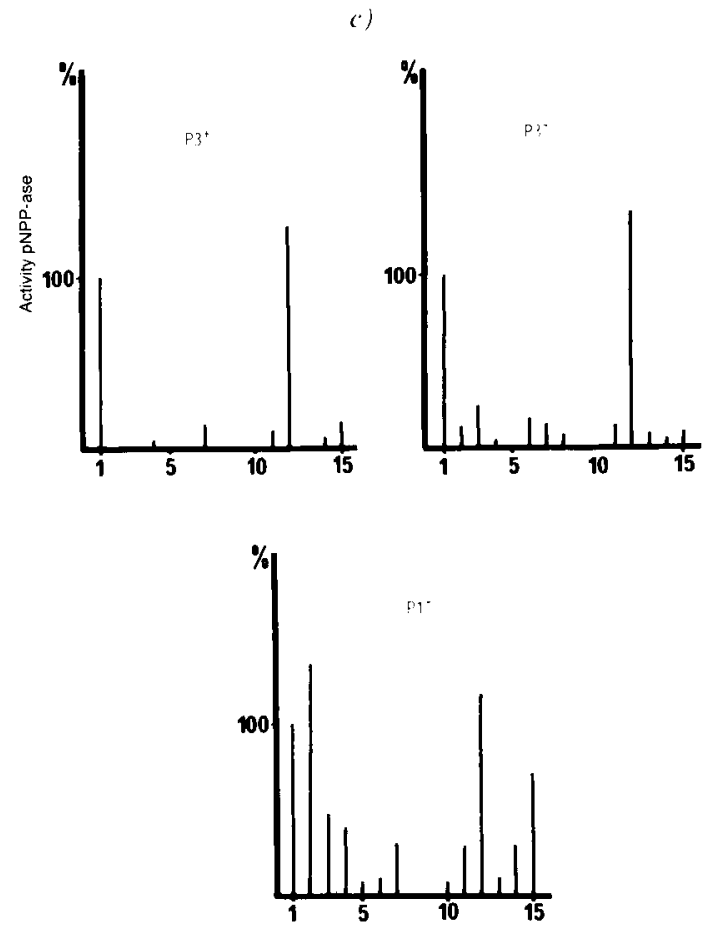

Figures 4

Specificity of soluble acid phosphatases from Pisolithus tinctorius (4a), Pinus halepensis (4b) and Pinus pinaster (4c).

Enzyme activities, expressed as a percentage of the activity measured with p-nitrophenyl phosphate ( $p N P P)$.

Activité spécifique des phosphatases acides solubles de Pisolithus tinctorius (4a), de Pinus halepensis (4b) et de Pinus pinaster (4c). Les activités enzymatiques sont exprimées en pourcentage de l'acti vité mesurée avec le p-nitrophényl phosphate (pNPP).

$1: p N P P ; 2:$ trimeta $P ; 3:$ tripoly $P ; 4:$ o-P-serine $; 5:$ bis pNPP ; $6:$ phytate ; $7:$ pyro $P ; 8: A T P ; 9: A D P ; 10: A M P$; $11:$ 1-naphtyl $P ; 12: 2$-naphtyl $P ; 13:$ glucose $1 P ; 14:$ glucose $6 P ; 15: \beta$-glycero $P$.

noticeably hydrolyse this compound. It should be interesting to research for the significance of this fact in natural conditions.

The phosphatases may play a role in releasing phosphate which is not directly assimilable by the plant (BIELESKI, 1973). One can suppose that the fungus possesses a better system of adaptation to limiting conditions than the pines since the soluble phosphatases of $P$. tinctorius have slightly more affinity for a model substrate such as pNPP and more activity for natural substrates than those of the pines. This could indicate that the phosphatases have some importance in the transport of Pi when its availability is limited (BouTIN et al., 1981 ; WOOLHOUSE, 1969). These results suggest that phosphatase activities could be a good criterion for the selection of fungi for ectomycorrhizal inoculation in plant nurseries.

Reçu le 21 juillet 1986. Accepté le 21 novembre 1986. 


\section{REFERENCES}

Bieleski R. L., 1973. Phosphate pools, phosphate transport and phosphate availability. Annu. Rev. Plant Physiol., 24, 225-252.

Boutin J. P., Provot M., Roux L., 1981. Effect of cycloheximide and renewal of phosphorus supply on surface acid phosphatase. Physiol. Plant., 51, 353-360.

Bowen G. D., 1973. Mineral nutrition of ectomycorrhizae, pp. 151. 205. In G. C. MARKS \& T. T. KOSLOWSKY. Ectomycorrhizeae, their ecology and physiology. Academic Press, New-York London.

Calléja M., Mousain D., Lecouvreur B., d'Auzac J., 1980. Influence de la carence phosphatée sur les activités phosphatases acides de trois champignons mycorhiziens, Hebeloma edurum Metrock, Suillus granulatus (L. \& Fr.) O. Kuntze, Pisolithus tinctorius (Pers.) Cocker \& Couch. Physiol. Vég., 18, 489-504.

Calléja M., d'Auzac J., 1983. Activités phosphatases et carences phosphatées chez les champignons supérieurs. Can. J. Bot., 61, 7986.

Coupé M., d'Auzac J., 1979. Phosphatases et ATP-ases liées aux parois squelettiques. Physiol. Vég., 17, 801-815.

Doumas P., Coupé M., d'Auzac J., 1983. Effet de la carence en phosphate sur les activités des phosphatases racinaires du Pin d'Alep. Physiol. Vég., 21, 651-663.

Doumas P., 1984. Influence de la carence en phosphate et de la mycorhisation sur les phosphatases racinaires de deux espèces $d u$ genre Pinus (Pinus halepensis et Pinus pinaster). Thèse Doct. $3^{\text {e }}$ Cycle, USTL, Montpellier.

Gianinazzi-Pearson V., 1982. Importance des mycorhizes dans la nutrition et la physiologie des plantes, pp. 51-59. In Colloques I.N.R.A., 13. Les mycorhizes : Biologie et utilisation. I.N.R.A Paris, $397 \mathrm{p}$

Ho I., Zak B., 1979. Acid phosphatase activity of six ectomycorrhizal fungi. Can. J. Bot., 57, 1203-1205.
Howeler R. H., Edwards D. G., Asher C. J., 1981. Application of the flowering culture selection technique to studies involving mycorrhizas. Plant and Soil, 59, 179-183.

Komano T., 1975. Formation of multiple forms of acid and alkaline phosphatases in relation to culture age of Aspergillus niger. Plant Cell. Physiol., 16, 643-658.

Mousain D., Salsac L., 1982. Nutrition phosphatée et activité phosphatase acide des symbiotes mycorhiziens cultivés isolément ou en association, pp. 87-100. In Colloques I.N.R.A., 13, Les mycorhizes : biologie et utilisation, I.N.R.A. Paris, 397 p.

Ninomiya Y., Ueki K., Sato S., 1977. Chromatographic separation of extracellular acid phosphatase of tobacco cells cultured under $\mathrm{Pi}$ supplied and -omitted conditions. Plant Cell Physiol., 18, 413-420.

Strother S., 1984. Control of phosphatase activities of duckweed by senescence and phosphorus deficiency. Biol. Plant., 26, 309-311.

Taussky H. H., Shorr E., 1953. A microcolorimetric method for the determination of inorganic phosphorus. J. biol. Chem., 202, 675685

Torriani A., 1960. Influence of inorganic phosphate in the formation of phosphatases by Escherichia coli. Biochim. biophys. Acta, 38, $460-479$.

Van Rijn H. J. M., Boer P., Steyn-Parvé E. P., 1972. Biosynthesis of acid phosphatase of baker's yeast. Factors influencing its production by protoplasts and characterization of the secreted enzyme. Biochim. biophys. Acta, 268, 431-441.

Woolhouse H. W., 1969. Differences in the properties of the acid phosphatases of plant roots and their significances in the evolution of edaphic ecotypes, pp. 357-380. In I. H. Robinson. Ecological aspects of the mineral nutrition of plants. Blackwell, Oxford, Edinburgh. 